\title{
How Learning Organization Supports the Intellectual Capital Field Study at Jordanian Banks
}

\author{
Hamdan Hasan Al-Onizat \\ Al-Balqa Applied University, Assalt- Jordan \\ Faculty of Planning and Management \\ Department of Management Information Systems \\ Tel: 962-79-931-2448_E-mail: enizat80@hotmail.com
}

Received: June 3, 2012

Accepted: June 28, 2012 Published: July 1, 2012

doi:10.5296/jmr.v4i3.1894

URL: http://dx.doi.org/10.5296/jmr.v4i3.1894

\begin{abstract}
The purpose of this paper is to investigate empirically the relation between the learning organization and intellectual capital. Correlation analysis and regression analysis was conducted with a sample of the main banks in Jordan. The application of this study was limited to employees in the Jordanian banking industry in 2010, and the results of this study on the implications of validity and reliability of the tools in the study used. The results support the hypothesis that learning organization has a positive impact on banks intellectual capital. The results extend the understanding of the role of organizational learning in creating intellectual capital and building sustainable advantages for banks in emerging economies, where different technological advancements may bring different implications for valuation of intellectual capital.
\end{abstract}

Keywords: Banking Industry, Intellectual Capital, Jordan, Learning organizations. 


\section{Introduction}

The increase of knowledge and its relationship with the learning process is a very important for all centuries (Ives et al., 1998; Blumentritt and Johnston, 1999). It is widely accepted that firms which invest in the creation of new knowledge and increasing the intellectual capital through research and development activities or tend to do better than those that ride on the coat of knowledge created by others (Boisot, 1998). This highlights the importance of the creation of intellectual capital as a critical component of an organization's ability to learn and adapt. This will be developed further in this paper as a focal point for analysis of the synergies between the learning organization and intellectual capital.

The term of the learning organization is increasingly relevant to twenty-first century management (Malhotra, 1996). It is therefore important to understand what a learning organization is, what its characteristics are and how it relates to the emerging topic of intellectual capital.

This paper addresses the question of whether fostering and supporting a learning organization is the same thing as intellectual capital at an organizational level. In the process of answering this question this paper will provide an explanation of the relationship between the learning organization (LO) as an entity and the discipline of intellectual capital. The research explain whether the learning organization in the banks sector in Jordan which have a continuous leakage in the intellectual capital. The results of this study will be usefully for the decision makers in the Jordanian banking sector.

\subsection{General Background To The Problem}

Competition in the new globalized environment became the main force to innovation in all sectors in the business, and the knowledge-based economy imposing the business to straggling against huge waves of the innovation and competition based on the knowledge that developed by the human and for the human. The intellectual capital which is the determinants of success of enterprises, and of national economies as a whole is ever more reliant upon their effectiveness in gathering and utilizing knowledge. Banks which is a main player in the Jordanian business environment have a deal with intellectual capital and as it a will structure enterprise in the Jordanian market have all basics of the learning organization which can support the intellectual capital. Globalization affect all business sector especially the financial institutions, especially those in the banking industry, have experienced a dynamic and competitive environment which must be faced by the investment and development in the information sector which leads the banking industry to adopts the learning organization as a solution to cope with this a problematic situation based on the intellectual capital which it have.

\section{Learning Organization and the Intellectual Capital}

\subsection{Learning Organization}

The Learning Organization by which we mean learning by the organization as a total system it is the organization skilled at creating, acquiring, and transferring knowledge, and at 
modifying its behavior to reflect new knowledge and insights in the business environment, Senge was one of those who early define the learning organization as an entity within which people continually expand their capacity to create the results they desire, where new and expansive patterns of thinking are nurtured, where collective aspiration is set free, and where people are learning to see the whole (reality) together (Senge, 1990). Goh (1998) contend that learning organizations have five foundation strategic building blocks: clarity and support for mission and vision, shared leadership and involvement, a culture that encourages experimentation, the ability to transfer knowledge across organizational boundaries, and teamwork and cooperation (Goh, 1998)

Learning Organization and the Intellectual capital became one of the most important issues that affect all kind of business including banking industry which face a demand for better products and services has a triggered growing in the in the managerial development, this development can be reach by the increase in the intellectual capital that the same organization can achieve it by the nature of being a learning organization. Senge define the learning organization as the strategies and initiatives for improving organizational effectiveness through emphases on developing the capabilities, capacities and qualities of the staff, and on approaches based on behavioral and attitudinal, as well as skills, enhancement (Senge, 1990). Senge established five disciplines in the learning organization (systems thinking, personal mastery, mental models, building shared vision and team learning) that he believed were necessary for an organization to be regarded as a learning organization which adopted in this paper. David Garvin's define the learning organization "A learning organization is an organization skilled at creating, acquiring, and transferring knowledge, and at modifying its behavior to reflect new knowledge and insights."(Garvin, 1998) Garvin (1998) saw the learning organization is skilled in five main activities: (1) systematic problem solving, (2) experimentation, (3) learning from past experiences, (d) learning from others, and (4) transferring knowledge. Garvin also postulate that learning must be monitored and measured.

The organizations must cope with challenges of the new economy, while analyzing the Learning Organizations Perechuda (2005) distinguish two trends, the first type of organizations are understood in dynamic organizational categories that are oriented at their development, searches for new chances on the market and continually increases their effectiveness, efficiency and flexibility. The second group of learning organizations consists of such entities that choose growth through development of their employees. Organizations of this type create conditions and encourage their members to constantly improve their qualifications and skills (Perechuda, 2005).

To support the learning organization there is an need to build a learning climate and culture. Climate and culture are built by leaders and other key people who learn from their experience, control the learning of others, and produce an environment of expectations that shapes and supports desired results. The learning process start from the individual level, Kurt Lewin (1946), helps explain how people shape this climate or culture for learning. Learning takes place when disjuncture's, discrepancies, surprises, or challenges act as triggers that stimulate a response. Individuals select a strategy or action based on their cognitive and affective understanding of the meaning of the initial trigger. Once a strategy or plan of action is 
determined, the individual implements the strategy. The strategy then either works or does not work as expected. When it does not work, there is dissonance and the cycle is triggered again (Kurt Lewin, 1946).

On the other hand, learning at the organizational level, what is most important at the organizational level is that learning is now a combined experience and learning the stages of learning may be similar, but learning is now the result of an interactive, interdependent process. The dynamic scanning of the environmental context of the organization, both internal and external, enables the organization to proactively shape response; the strategy's success is due in part to the organization's ability to act cohesively. Once the organization responds, individuals and departments make assumptions about the effectiveness of that response. There are consequences for both individuals and organizations as a result of these actions. Considerable learning may be required at the individual level before the organization has a new capacity. Organizational learning is the network result of this cycle. Learning by individuals is necessary for the organization to change but not sufficient, Argyris \& Schon (1996) explain that when individuals increase their capacity to learn, they can (cooperatively) improve the overall capacity of the organization to learn as long as the organization is receptive to their efforts to use their learning and puts in place appropriate mechanisms to enable, support, and reward the use of what is learned. Thus, individual learning is related to organizational learning though not equal to it and potentially interdependent with it (Argyris \& Schon, 1996).

\subsubsection{Benefits of Learning Organizations}

Rose (1997) explain that the twenty first century is the century of knowledge. There are many benefits to improving learning capacity and knowledge sharing within an organization:

- Maintaining levels of innovation and remaining competitive

- Being better placed to respond to external pressures

- Having the knowledge to better link resources to customer needs

- Improving quality of outputs at all levels

- Improving corporate image by becoming more people orientated

- Increasing the pace of change within the organization (Rose,1997).

2.1.2 The learning organization and organizational learning

The process of organizational learning is defined as "increasing an organization's capability to take effective action" (Kim, 1998). The learning organization, for the sake of simplicity, is defined as an organization that embraces (either consciously or unconsciously) the principles of organization learning and supports an environment where organization learning can flourish. Schein (1997) identified a useful distinction made by Lundberg between organization learning, by which we typically mean learning by individuals and groups in the organization, versus the learning organization by which we typically mean learning by the organization as a total system (Kim, 1998). 
When discussing learning processes in this paper, the term organization learning will be used and contrasted with the generic process of learning organization. Predominantly however, this paper will focus on the learning organization which, as an entity, will be compared to banks that are skilled in the disciplines of intellectual capital.

\subsection{Intellectual Capital}

Intangible assets have become more important to business success than the traditional factors of production - land, labour and financial capital (Edvinson and Malone, 1997; Sveiby, 1997; Stewart, 1998). Furthermore, organizational knowledge assets are a major component of these intangible assets. Intellectual capital is defined as the sum of intangible assets related to knowledge of a company that have been formalized, captured, and leveraged to produce a higher-valued asset and to create competitive advantage (Berry, 2004; Stewart, 1997; Subramaniam and Youndt, 2005). The understanding of the learning organization and its connection with the generation of organizational knowledge is far from clear (Schein, 1997; Gourlay, 1999; Macleod, 1999). The most widely used definition of intellectual capital is "knowledge that is of value to an organization." Its main elements are human capital, structural capital, and customer capital. That definition suggests that the management of knowledge (the sum of what is known) creates intellectual capital (Bassi,1997).

Intellectual capital was described by Stewart as a "brand new tennis ball—fuzzy, but with a lot of bounce." However, this statement acts as a detriment for the continued existence of this field in academia. Most "bouncy" topics that are researched extensively (e.g., reengineering, quality circles, management by objectives) are frowned upon in academic circles because they are considered nothing more than popular fads. Due to their temporal shortcomings, they are deemed unworthy of serious study. Thus, the "fuzzy" aspect of intellectual capital captures the curious interest of practitioners who are always on the prowl for finding solutions to difficult challenges, popularity of this topic during its genesis has been sponsored by business practitioners. It is for this audience that the conceptualization of intellectual capital resonates most (Bontis, 2002). Intellectual capital is knowledge that can be exploited for some profitable or other useful purpose. The term combines the idea of the intellect or mental power with the economic concept of capital, the saving of entitled benefits so that they can be invested in producing more goods and services (Teece, 1997). Intellectual capital can include the skills and knowledge that a bank has developed about how to make its or services; individual employees or groups of employees whose knowledge is deemed critical to a banks continued success; and its aggregation of documents about processes, customers, research results, and other information that might have value for a competitor that is not common knowledge. Managing intellectual capital as a matter of common business sense is not sufficient for the development of intellectual capital management as an organizational competency. It is only when a management style moves from being intuitively applied to a planned and systemized process that it can be perfected. Only then can it be substantially transformed from being an art to becoming a science, once it transitions into a science, it becomes testable, measurable, more predictable, and, most importantly, repeatable. 


\subsubsection{The Dynamic Capabilities of Intellectual Capital}

Teece (1997) defined dynamic capability as "the firm's ability to integrate, build and reconfigure internal and external competencies to address rapidly changing environments". Winter (2002) addressed in more details the issue of dynamic capabilities. He made a distinction between ordinary "zero level" capabilities, (i.e. those capabilities that "permit to the firm to make living in the short term") from dynamic capabilities that contribute to the expansion, alteration or creation of ordinary capabilities. The actual problem with intellectual capital lies in its measurement(Sveiby,2001). Unluckily, an invisible conceptualizationregardless of its underlying simplicity-becomes an abyss for the academic researcher. To make matters worse, intellectual capital is conceptualized from numerous disciplines, making the field a mosaic of perspectives (Davis,2009), According to Strassman (1998), intellectual capital is what is left over after suppliers, employees, creditors or shareholders and the government have been paid, and obsolete assets replaced, therefore the intellectual capital is very difficult to measure.

All literature review insures that components of intellectual capital consist of human capital, structural capital and external (customer) capital, which will be search whether it affected by the learning organization in the banks sector in Jordan which have a continuous leakage in the intellectual capital. Intellectual capital initially started to appear in the press in the early 1990s (1997). This problem was identified even earlier by Nonaka and Takeuchi (1995) who stated that "organizational learning theories basically lack the view that knowledge development constitutes learning and most OL theories concentrate on individual learning and have not developed a comprehensive view of learning at an organizational level". According to Sandelands (1999) and Amidon (1996), organizations that are not able to embrace shared learning and knowledge generation at the organizational level simply disappear. Brown and Woodland (1999) add further insight into the learning/knowledge synergy by claiming that "it is impossible for an organization to sustain competitive advantage without constantly learning and developing new knowledge". The organizational culture has to contain many motivators to continually expand that knowledge. This fact has already been noticed by individual human beings. Organizations will not only have to notice the requirements of the present, but also adjust to them. This adjustment has to go in two stages. First, it is necessary to become aware of the necessity of corporate knowledge development and take dealings that aim at the development of intangible assets of the corporation, and then taking particular actions from the scope of implementing knowledge management systems and elimination of numerous barriers that occur and that significantly decrease the effectiveness of the adopted strategies, in particular knowledge acquisition strategy (Figure 1). 


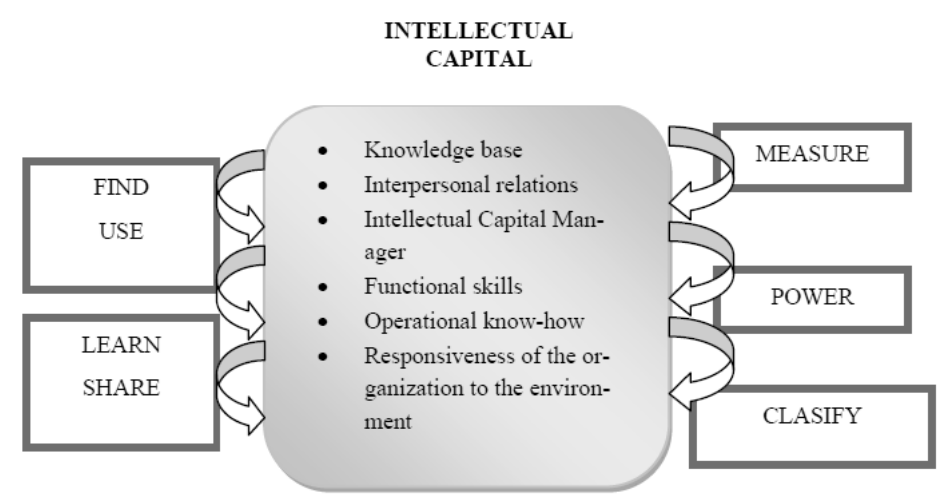

Figure 1. The process of intellectual capital management (Bukowitz \& Williams, 2001)

The realization that intellectual capital constitutes a growing part of our equity markets is not a problem in itself. The problem is that when non-recognized intellectual capital as a proportion of market value increases, the proportion of market value accounted for by the balance sheet decreases. And if financial reporting fails to include information on this value-creating intellectual capital, the risk exists that an under-provision of such information will result in a less efficient valuation of equity, which will in turn undermine the general aim of optimal resource allocation by the capital market. High speed change in the extant global business environment demands high-speed learning and with the rate of change continuing to increase relentlessly, pressure on learning at organizational level has never been greater. This requires new knowledge to be generated continuously and managed in a systematic way. The combined disciplines of the learning organization and intellectual capital give the framework in the banking industry.

\section{Learning Organization and the Intellectual Capital in Banking Industry}

Most literature addressing intellectual capital have focused on the correlation between intellectual capital and organizational performances (Chong and Lin, 2008; Ho, 2009). There are relatively few discussions on the relationship between learning organization and intellectual capital, and even fewer studies on such a relationship in the banking industry. The core competitiveness of the banking industry is highly reliant on the ability of management teams to systematically being a learning organization. It also depends on whether they are able to create sophisticated skills catering to the intellectual capital of their organization to effectively manage risks and create profits. Few studies were conducted to discover the relationship between the learning organization and the intellectual capital in the banking industry, in the literature there is a lack of study about the Jordanian banking industry.

Al-Nsour and Al-Weshah (2001) extend the understanding of the role of organizational learning in creating intellectual capital and building sustainable advantages for banks in emerging economies(Al-Nsour and Al-Weshah,2011)

Financial sources are essential for all sectors in a country's economy, so banking sector is indispensable for a sustainable economical growth. In order to keep up in today's competitive 
banking sector, banks need to offer more value added and more diversified services. As the service quality of banks highly depends on intellectual capital, banking sector provides a great research opportunity for intellectual capital studies (Goh, 2005). Pulic (2002) used VAIC $^{\mathrm{TM}}$ model, which he developed, measured intellectual capital performance of Austrian banks in 1993-1995 and Croatian banks in 1996-2000. They revealed significant differences in bank ranking based on efficiency and performance. As a whole, all banks have relatively higher human capital efficiency than structural and capital efficiencies. Domestic banks were generally less efficient compared to foreign banks. There were significant differences between rankings of bank according to efficiency and traditional accounting measures. $\mathrm{G}$. Barathi Kamath (2008) estimate and analyze the Value Added Intellectual Coefficient $\left(\mathrm{VAIC}^{\mathrm{TM}}\right.$ ) for measuring the value-based performance of the Indian banking sector for a period of five years from 2000 to 2004. The study confirms the existence of vast differences in the performance of Indian banks in different segments, and there is also an improvement in the overall performance over the study period(Bharathi Kamath,2010). Intellectual capital is increasingly acceptable as an important factor for sustainable corporate advantages. The importance of intellectual capital in enhancing firm profitability and cost efficiency. Developing intellectual capital is no less important than capital investments for companies. Therefore, Intellectual capital should be increasingly recognized as one of the major investment for driving the company's sustainable growth, together with the other factors of production.

This paper examines a empirical study on learning organization and intellectual capital to generalize the important factors concerning learning organization and intellectual capital of banks. The major purpose is to explore the relationship between learning organization and intellectual capital through the construction of the correlation patterns between these two elements. This paper hopes to provide practical suggestions for the reference of the management of Jordanian banks.

\section{Research Objectives}

The objective of this research is to test how learning organization support the intellectual capital. In this research it's attempted that the vacuum resulted from the lack of related researches be filled and the significance for the relation of these two variables be verified.

\section{Research Conceptual Model}

Based on the theoretical studies which have been done for this research which are mostly expressed that the five disciplines in the learning organization (systems thinking, personal mastery, mental models, building shared vision and team learning) and components of intellectual capital (human capital, structural capital and external (customer capital) was the components of the study model (Figure 1) which has been designed to indicate the relation, According to this model, the hypotheses of the research have been compiled. 


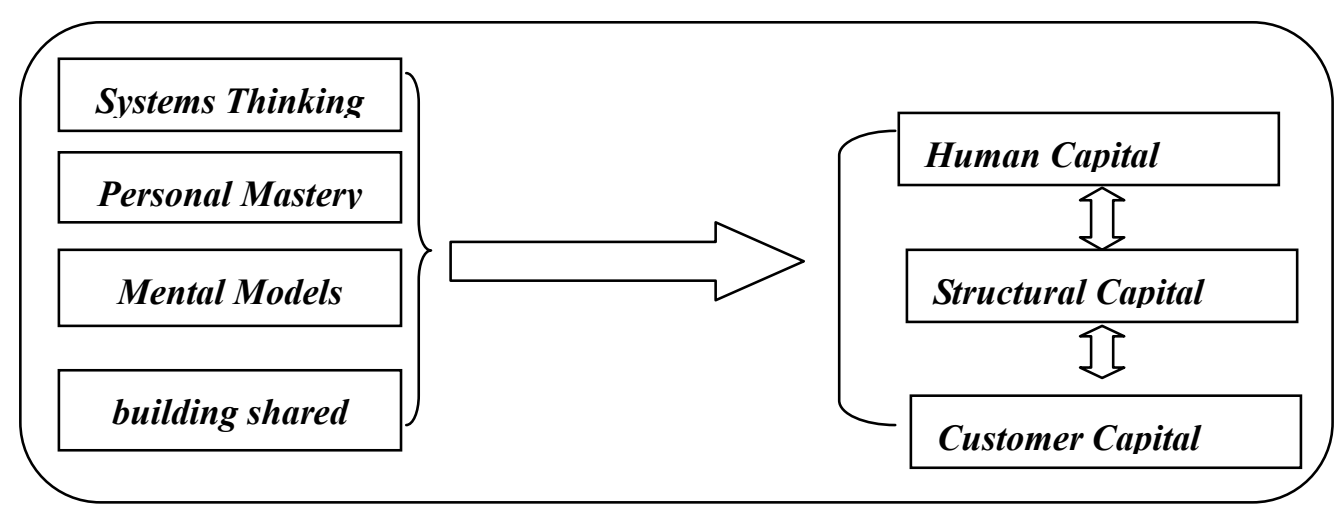

Figure 2. Conceptual model of research

\section{Research Hypotheses}

This research has one main hypothesis:

Learning Organization has positive impact on Intellectual Capital.

In order to test this hypothesis, three other sub hypotheses:

1.1 Learning Organization has positive impact on Human Capital.

1.2. Learning Organization has positive impact on Structural Capital.

1.3. Learning Organization has positive impact on Customer Capital.

\section{Methodology}

\subsection{Sampling}

The quantitative approach was adopted in the research and hypotheses testing approach are used to attain the study aim and objectives. The selected sample of the study the way random from all employees in the Jordanian banking industry, and thus formed the study sample of (250) employees.

The instrument was taken from literature and it developed to be stable for the sample that has been taken. The self management distributed questionnaire have been collected, the correct questionnaire was (167) after exclusion the invalid. employers and employees, of whom (96) and factor (71) and the employee, the table shows (1) the distribution of members of the sample of the study . 
Table 1. Sample distributions

\begin{tabular}{llll}
\hline Variables & Levels & $\mathrm{N}$ & Percentage \\
\hline Gender & Male & 96 & 45.5 \\
& Females & 71 & 54.5 \\
Experience & Less than 5 years & 61 & 36.4 \\
& 5-10 years & 38 & 22.7 \\
Qualifications & More than 10 years & 68 & 40.9 \\
& Bachelor or below & 144 & 86.4 \\
& Graduate & 23 & 13.6 \\
\hline
\end{tabular}

\subsection{Instrument}

To achieve the goal of the study, the researcher developed a instrument to measure the variables of the study, and formed a tool of the study (60) items of which (32) items measures the learning organization are distributed on three areas: learning organization and impact on human capital, learning organization and impact on structural capital, learning organization and impact on customer capital. using a standard Likert scale five-rank, which range answer from one degree to the answer (very few), and two degrees to the answer (a few), and three degrees to the answer (medium), and four degrees to the answer (large), and five degrees before the answer (very large), and consisted tool study of three parts: the first part of primary data and are: gender (male, female), experience (less than 5 years, 5-10 years, and more than 10 years), and Qualification (BA and below, postgraduate).

\section{Validity and Reliability of Questionnaire}

Reliability is a mechanism employed to check the internal consistency of test questions against every other test item when completed by different participants. In order to estimate reliability, 25 questionnaires were sent to employees. Overall Cronbach's alpha for the sample was 0.89 which indicate an excellent level of statistical internal consistency. Sequentially to increase the content validity of the research instrument, the questionnaire was "pilot-examined" by interviewing 20 managers and experts in the banking industry who agreed to fill in the questionnaire and also to comment on the scales employed. Then, their suggestions were collected and some reformations were made to improve validity of questionnaire.

\section{The Limits of the Study and its Determinants}

The boundaries of the study and its determinants as follows:

- The application of this study was limited to employees in the Jordanian banking industry in 2010 makes the results of the study cannot be generalized for all Jordanian banking industry.

- The results of this study depend on the implications of validity and reliability of the tools in the study used. 


\section{Analytical Procedures}

To achieve the objectives of the study was the use of statistical software packages for the Social Sciences (SPSS) to answer the questions of the study.

\section{Hypotheses Test}

In order to test hypotheses research, we used SPSS software. The results of the analysis have been discussed below.

Hypothesis 1.1: Learning Organization has positive impact on Human Capital:

\begin{tabular}{|l|l|l|l|l|l|l|}
\hline \multirow{2}{*}{ Hypothesis 1.1 } & $\begin{array}{l}\text { Dependent } \\
\text { variable }\end{array}$ & $\begin{array}{l}\text { Independent } \\
\text { variable }\end{array}$ & R square & Standard $\beta$ & T test & Result \\
\cline { 2 - 6 } & $\begin{array}{l}\text { Intellectual } \\
\text { Capital }\end{array}$ & $\begin{array}{l}\text { Organizational } \\
\text { Learning }\end{array}$ & 0.286 & 0.272 & 3.040 & $\underline{\text { Confirmed }}$ \\
\hline
\end{tabular}

According to the results, Beta Standard ratio is calculated 0.272 which is significant. Thus, this hypothesis is confirmed and Learning Organization has positive impact on Human Capital.

Hypothesis 1.2: Learning Organization has positive impact on Structural Capital:

\begin{tabular}{|l|l|l|l|l|l|l|}
\hline & $\begin{array}{l}\text { Dependent } \\
\text { variable }\end{array}$ & $\begin{array}{l}\text { Independent } \\
\text { variable }\end{array}$ & R square & Standard $\boldsymbol{\beta}$ & T test & Result \\
\cline { 2 - 6 } & $\begin{array}{l}\text { Intellectual } \\
\text { Hypothesis 1.2 }\end{array}$ & $\begin{array}{l}\text { Organizational } \\
\text { Learning }\end{array}$ & 0.341 & 0.194 & 2.857 & $\underline{\text { Confirmed }}$ \\
\hline
\end{tabular}

According to the results, Beta Standard ratio is calculated 0.194 which is significant. Thus, this hypothesis is confirmed and Learning Organization has positive impact on Structural Capital.

Hypothesis 1.3: Learning Organization has positive impact on Customer Capital:

\begin{tabular}{|l|l|l|l|l|l|l|}
\hline \multirow{2}{*}{ Hypothesis 1.3 } & $\begin{array}{l}\text { Dependent } \\
\text { variable }\end{array}$ & $\begin{array}{l}\text { Independent } \\
\text { variable }\end{array}$ & R square & Standard $\boldsymbol{\beta}$ & T test & Result \\
\cline { 2 - 6 } & $\begin{array}{l}\text { Intellectual } \\
\text { Capital }\end{array}$ & $\begin{array}{l}\text { Organizational } \\
\text { Learning }\end{array}$ & 0.207 & 0.341 & 3.218 & $\underline{\text { Confirmed }}$ \\
\hline
\end{tabular}

According to the results, Beta Standard ratio is calculated 0.341 which is significant. Thus, 
this hypothesis is confirmed and Learning Organization has positive impact on Customer Capital.

\section{Conclusions}

The concepts of the learning organization and intellectual capital have been shown to be closely related and mutually supporting. The learning organization and learning organization as the heart and lungs of a living organism, so the banking industry must invest to transform to the learning organization which in then will increase the intellectual capital, consequently it will go forward in the competitive globalized environment.

Having established the synergies between the learning organization and intellectual capital, the management challenge now is to further develop the meanings and implications arising from the combined utilization of these disciplines. The messages that emerge from this paper and opportunities for further research can be summarised as follows:

1. Learning organization and the intellectual capital are inextricably linked to the extent that they should taken in mind of the banking industry planers.

2. Organizations should focus on the total inter-organization learning process (i.e. the creation of new corporate knowledge from the total environment within which the organization operates) and the nurturing of the cultural environment that supports it and ensures its continuing development.

Most banks have adapted or transformed their management styles and business models to manage intellectual capital and respond to the intellectual capital enabled dynamics of the knowledge economy. Many of these banks have done it without even realizing that they are adopting an intellectual capital management, banks managers should provide themselves with the latest knowledge so that they could overcome to the forthcoming events. This important as stated earlier is possible with competent employees and managing them effectively. Also managers should note that; that organizations are operating in a vacuum is not surprising, as they do not have any methods or tools to use that would enable them to analyze their intellectual capital stocks and organizational learning flows.

Despite the limitations of using data, the present study provides valuable insights into the association between intellectual capital and financial performance. Finally, this study helps to extend the current research agenda on the intellectual capital discipline in the area of learning organizations.

\section{References}

Amidon, D.M. (1996). The momentum of knowledge management. Journal for Industrial Research Institute.

Argyris, C., \& Schon, D. (1996). Organizational learning II: Theory, method, and practice. Reading, MA: Addison-Wesley

Bassi, Laurie, J. (1997). Harnessing the power of intelectual capital. Training \& Development, 51(12). 25-30. 
Berg, H.A. (2002). Models of Intellectual capital Valuation: A Comparative Evaluation,http://business.queensu.ca/knowledge/consortium2002/ModelsofICValuation.pdf

Berry, J. (2005). Tangible strategies for intangible assets: how to manage and measure your company's brand, patents, intellectual property, and other sources of value. New York: McGraw-Hill.

Bharathi Kamath G. (2010). The Intellectual Capital Performance of Banking Sector in Pakistan, 4(1). 84-99. Pak. J. Commer. Soc. Sci.

Blumentritt, R., \& Johnston, R. (1999). Towards a strategy for knowledge management. Technology Analysis \& Strategic Management. http://dx.doi.org/10.1080/095373299107366

Boisot, M., (1998). The information space (I-space). Knowledge Assets: Securing Competitive Advantage in the Information Economy, Oxford University Press, New York, NY.

Bontis, Nick. (1996). There's a price on your head: Managing intellectual capital strategically. Business Quarterly (summer).

Brooking, A., (1998). Intellectual Capital: Core Asset for the Third Millennium Enterprise, Thompson Business Press, London, 52.

Brown, R.B., \& Woodland, M.J. (1999). Managing knowledge wisely: a case study in organizational behavior. Journal of Applied Management Studies.

Bukowitz, W., \& Williams, R. (2001). Knowledge management fieldbook. Business Digest, February.

Chong, S.C., \& Lin, B. (2008). Exploring knowledge management (KM) issues and KM performance outcomes: empirical evidence from Malaysian multimedia super corridor companies. International Journal of Technology Management, 43(4), 285-303. http://dx.doi.org/10.1504/IJTM.2008.020552

Davis, Mark. (2009). The value of knowledge management, [Online] Available: http://www.knowledgepoint.com.au/intellectual_capital/Articles/IC_MD001c.html Demset

Edvinson, L., \& Malone, M., (1997). Intellectual Capital: Realizing Your Company's True Value by Finding its Hidden Brainpower, HarperBusiness Press, New York, NY, 3.

G. Bharathi Kamath. (2008). Intellectual capital and corporate performance in Indian pharmaceutical industry. Journal of Intellectual Capital, 9(4), 684-704. http://dx.doi.org/10.1108/14691930810913221

Garvin, D.A. (1993). Building a Learning Organization. Harvard Business Review.

Goh, P.C. (2005). Intellectual capital performance of commercial banks in Malaysia. Journal of Intellectual Capital, 6(3), 385-396. http://dx.doi.org/10.1108/14691930510611120

Goh, S. C. (1998). Toward a learning organization: The strategic building blocks. S.A.M. Advanced Management Journal, 63(2), 15-20. 
Gourlay, M.J. (1999). Foundationalism: the problem of knowledge, www.xs4all.nl/-nexus/gourlay/found_prob.html.

Kim, D. H. (1998). The Strategic Management of Intellectual Capital, Butterworth-Heinemann, Woburn. MA, 41-62. http://dx.doi.org/10.1016/B978-0-7506-9850-4.50006-3

Lewin, K. (1946). Action research and minority problems. Journal of Social Issues, 2(4). 34-46. http://dx.doi.org/10.1111/j.1540-4560.1946.tb02295.x

Macleod, M. (1999). The knowledge chain, Supply Management.

Malhotra, Y. (1996). Organizational learning and learning organizations: an overview, [Online] Available: www. brint.com/papers/orglrng.htm.

Marwan M. Al-Nsour, \& Ghazi A. Al-Weshah. (2011). Learning Organization and Intellectual Capital: An Empirical Study of Jordanian Banks. European Journal of Business and Management, 3(8), 12-23.

McGill, M.E., Slocum, J.W., \& Lei, D (1993). Management practices in learning organizations, Organizational Dynamics.

Nissen, M., Kamel, M., \& Sengupta, K. (2000). Integrated analysis and design of knowledge systems and processes. Information Resources Management Journal. http://dx.doi.org/10.4018/irmj.2000010103

Nonaka, I. (1998). The knowledge-creating company, Harvard Business Review on Knowledge Management. Harvard Business School Press, Boston, MA, 21-45.

Nonaka, I., \& Takeuchi, H. (1995). The Knowledge Creating Company, Oxford University Press, New York, NY, 8, 10, 44-5, 238-9.

Perechuda, K. (Ed.) (2005). Zarzqdzanie wiedzq w przedsiębiorstwie [Knowlegde management in organization]. Warszawa: PWN.

Pulic, A. (2002). Value Creation Efficiency of Croatian Banks 1996 - 2000 , February, 2002 [Online] Available: www.vaic-on.net

Roos, J., G. Roos, Edvinsson L., \& N.C. Dragonetti. (1997). Intellectual Capital: Navigating in the New Business Landscape. New York: Macmillan.

Sandelands, E. (1999). Learning organizations: a review of the literature relating to strategies, building blocks and barriers. Management Literature in Review, 1 .

Santosus, M., (1996). The learning organization, CIO Magazine.

Schein, E.H. (1997). Organizational Learning: What is New? Society for Organizational Learning. MIT Sloan School of Management, Cambridge, MA.

Senge, P. M. (1990). The fifth discipline: The art and practice of the learning organization. New York: Doubleday/Currency. 
Stewart, T.A. (1997). Intellectual Capital: The New Wealth of Organizations. New York: Doubleday.

Stewart, T.A. (1998). Intellectual Capital: The New Wealth of Organizations, Nicholas Brealey Publishing, London, 6, 12, 66-7.

Stewart, T.A., (1995). Mapping corporate brainpower, [Online] Available: http://pathfinder.com.

Sveiby, K.E. (1994). Towards a knowledge perspective on organization, doctoral thesis, University of Stockholm, Stockholm.

Sveiby, K.E. (1997). The New Organizational Wealth: Managing and Measuring Knowledge-based Assets, Berrett-Koehler Publishers, San Francisco, CA, 5, 8-9, 23, 29, 34.

Sveiby, K-E. (2001) Intellectual capital and knowledge management, [Online] Available: http://www.sveiby.com/articles/IntellectualCapital.html

Teece, D., Pisano, G., \& Shuen, A. (1997). Dynamic capabilities and strategic management. Strategic Management Journal, $\quad$.509-33. http://dx.doi.org/10.1002/(SICI)1097-0266(199708)18:7<509::AID-SMJ882>3.0.CO;2-Z

Winter, S. (2002). Understanding dynamic capabilities. Working Paper WP 2002-05, Regional H. Jones Center, The Wharton School, University of Pennsylvania. 